\title{
23 Effects of Slurry With and Without the Nitrification Inhibitor Dicyandiamide on Soil Mineral Nitrogen and Nitrogen Response of Potatoes
}

\author{
W. P. WADMAN, J. J. NEETESON and G. WIJNEN \\ Institute for Soil Fertility, PO Box 30003, 9750 RA Haren, The \\ Netherlands
}

\begin{abstract}
In the period 1983-1985, 18 potato experiments with poultry slurry were conducted on soils reclaimed from cut-over peat and sandy soils in the Netherlands. The experiments consisted of four main treatments: no slurry, autumn-applied slurry, autumn-applied slurry combined with the nitrification inhibitor dicyandiamide (DCD), and spring-applied slurry. As calculated from the amount of soil mineral nitrogen present at the start of the growing season (June), average nitrogen recoveries of 47,62 and $51 \%$ were found for autumn-applied, autumn-applied with DCD and spring-applied slurry respectively. A close relationship was found between the amount of soil mineral nitrogen in June and the amount of nitrogen contained in the tubers of the potatoes at harvest. Soil mineral nitrogen at harvest was increased by even moderate amounts of nitrogen supplied. At the optimum nitrogen supply for crop growth, about $110 \mathrm{~kg}$ of mineral nitrogen per ha remained in the soil profile $(0-100 \mathrm{~cm})$ at harvest. This could lead to considerable losses of nitrogen in the following winter.
\end{abstract}

\section{INTRODUCTION}

The value of organic manures in crop production in supplying nutrients and organic matter has long been recognized (Allison, 1973). However, during the past decades the production of animal manures has increased drastically 
and their use has adversely affected the environment in parts of the Netherlands and other regions of Europe (Wadman $e t$ al., 1987). One of the harmful effects is the pollution of groundwater due to leaching of nitrate.

One of the measures to reduce nitrogen (N) losses from ammoniumcontaining organic fertilizers applied in autumn is the use of nitrification inhibitors (Slangen and Kerkhof, 1984). The nitrification inhibitor dicyandiamide (DCD) inhibits the microbial oxidation of ammonium to nitrite and thus the formation of nitrate (Amberger, 1986). The loss of $\mathrm{N}$ through leaching or denitrification is therefore reduced.

DCD can be applied effectively together with slurry (Amberger, 1986). In soil, DCD is broken down to the harmless components $\mathrm{NH}_{3}, \mathrm{CO}_{2}$ and $\mathrm{H}_{2} \mathrm{O}$. The rate of degradation of DCD is largely determined by soil temperature. Vilsmeier (1980) reported that the concentration of DCD in the soil changed little during incubation for 80 days at $8^{\circ} \mathrm{C}$. At $14^{\circ} \mathrm{C}$, however, an increased breakdown of DCD was observed between 40 and 60 days after its application (Vilsmeier, 1980).

This paper describes experiments conducted in the Netherlands in the period 1983-1985. The response of potatoes grown for industrial starch production to inorganic $\mathrm{N}$ fertilizer and the combination of inorganic $\mathrm{N}$ fertilizer with slurry $\mathrm{N}$ was determined. Slurry was applied in autumn (with and without DCD) and in spring.

The effects of $\mathrm{N}$ fertilization on leaching of nitrate were evaluated by means of the amounts of soil mineral N. Preliminary results concerning the $\mathrm{N}$ response of the potatoes in the experiments described here were published earlier (de la Lande Cremer, 1986).

\section{MATERIALS AND METHODS}

In the period 1983-1985, 6 experiments with potatoes (Solanum tuberosum L.) grown for industrial starch production were conducted annually in the north-eastern part of the Netherlands on two soil types. The first soil type (Soil 1) is a soil reclaimed from peatland 50-150 years ago as follows: the peaty top layer was put aside and the underlying peat was removed. The top

Table 1. Characteristics of the soils reclaimed from cut-over peat and the sandy soils (Soils 1 and 2 respectively). All values pertain to the $0-30 \mathrm{~cm}$ layer.

\begin{tabular}{|c|c|c|c|c|c|c|c|}
\hline \multirow[t]{2}{*}{ Soil } & \multirow{2}{*}{$\begin{array}{l}\text { Number of } \\
\text { trials }\end{array}$} & \multicolumn{2}{|c|}{$\mathrm{pH}-\mathrm{KCl}$} & \multicolumn{2}{|c|}{ Organic matter $(\%)$} & \multicolumn{2}{|c|}{$N$ total $(\%)$} \\
\hline & & Mean & Range & Mean & Range & Mean & Range \\
\hline & 11 & 5.0 & & 13.7 & & 0.30 & \\
\hline 2 iSa & 7 & 4.6 & $4.0-5.2$ & 5.9 & $4.4-7.3$ & 0.15 & $0.11-0.22$ \\
\hline
\end{tabular}


Table 2. Amount of slurry applied and form and amount of $N$ contained in the slurry (including $\mathrm{N}$ from DCD in treatment c). Averages of 18 experiments.

\begin{tabular}{|c|c|c|c|c|}
\hline \multirow[t]{2}{*}{ Treatment } & \multirow{2}{*}{$\begin{array}{l}\text { Amount of } \\
\text { slurry applied } \\
\qquad\left(\mathrm{ha}^{-1}\right)\end{array}$} & \multicolumn{3}{|c|}{$\begin{array}{l}\text { Amount of } \mathrm{N} \text { contained in the slurry } \\
\qquad\left(\mathrm{kg} \mathrm{ha}^{-1}\right)\end{array}$} \\
\hline & & Inorganic & Organic & Total \\
\hline $\mathrm{b}$ (slurry in autumn) & 26 & 116 & 148 & 264 \\
\hline$c$ (slurry in autumn + DCD $)$ & 26 & 119 & 144 & 263 \\
\hline$d$ (slurry in spring) & 18 & 96 & 83 & 179 \\
\hline
\end{tabular}

layer was then replaced onto, and mixed with, the subsoil. The second soil type (Soil 2) is a sand. Relevant characteristics of the two soil types are given in Table 1.

At each site four treatments with poultry slurry were combined with six inorganic $\mathrm{N}$ fertilizer rates $\left(0,60,120,180,240\right.$ and $\left.300 \mathrm{~kg} \mathrm{~N} \mathrm{ha}^{-1}\right)$. Each treatment was replicated three times. The slurry treatments were (a) no slurry application, (b) slurry applied in late autumn (end of November to beginning of December), (c) slurry applied in late autumn with $20 \mathrm{~kg} \mathrm{DCD} \mathrm{ha}^{-1}$, and (d) slurry applied in spring (March or April). The amounts of slurry and slurry $\mathrm{N}$ applied are given in Table 2 .

After the slurry was applied it was incorporated into the soil as soon as possible to reduce $\mathrm{N}$ losses due to ammonia volatilization. The inorganic $\mathrm{N}$ fertilizer (ammonium nitrate limestone) was applied in spring as a single dressing.

Soil mineral $\mathrm{N}$ ( $\mathrm{N}$ in the form of ammonium or nitrate) was determined in three layers $(0-30,30-60$ and $60-100 \mathrm{~cm})$ in the autumn and the spring preceding the growing season of the potatoes, during the growing season, and after the harvest of the potatoes. The mineral $\mathrm{N}$ content of the soil was found by extracting soil samples with $1.0 \mathrm{M} \mathrm{NaCl}$ and determining the ammonium and the nitrate contents of the extract colorimetrically with an AutoAnalyzer (Ris et al., 1981).

At harvest (end of September to beginning of October) the tuber yield was determined and the tubers were analyzed for their $\mathrm{N}$ content using a Kjeldahl destruction and a mixture of $\mathrm{Na}_{2} \mathrm{SO}_{4}, \mathrm{Cu}$ and $\mathrm{Se}$ as a catalyst (Vierveijzer et al., 1979).

\section{RESULTS}

In the autumn preceding the growing season and before slurry was applied, on average $97 \mathrm{~kg} \mathrm{ha}^{-1}$ mineral $\mathrm{N}$ was found in the $0-100 \mathrm{~cm}$ layer of the soil 
Table 3. Ammonium and mineral $\mathrm{N}$ contents ( $\mathrm{N} \mathrm{kg} \mathrm{ha}^{-1}$ ) of the $0-100 \mathrm{~cm}$ soil layer in the autumn and spring prior to the growing season. Averages of 18 experiments and their standard error.

\begin{tabular}{llllll}
\hline & \multicolumn{2}{l}{ Ammonium } & & \multicolumn{2}{l}{ Mineral N } \\
Treatment & Autumn & Spring & & Autumn & Spring \\
\hline Means & & & & \\
d (no slurry) & 15 & 23 & 100 & 75 \\
b (slurry in autumn) & 15 & 107 & 93 & 240 \\
c (slurry in autumn + DCD) & 17 & 149 & 95 & 210 \\
d (slurry in spring) & 17 & 24 & 99 & 82 \\
Standard errors of means & 1.0 & 12.7 & 3.5 & 15.2 \\
\hline
\end{tabular}

(Table 3). In the following spring the ammonium and nitrate contents of the soil were determined before slurry was applied (treatment d). Slurry applied in autumn had increased the ammonium and mineral $\mathrm{N}$ content of the soil considerably (Table 3, treatments $b$ and $c$ ). DCD had increased the ammonium content of the soil significantly $(P<5 \%)$, but, on average, had decreased soil mineral $\mathrm{N}$ in spring (Table 3 ).

In June, at the start of the growing season, the ammonium content of the soil of treatments $b$ and $c$ had decreased. The effect of DCD on the ammonium content of the soil remained about the same as in spring (the difference between treatments $c$ and $b$ in Table 3 equals about the difference in Table 4).

Application of inorganic fertilizer $\mathrm{N}$ in April had increased the ammonium content of the soil in June (Table 4).

Table 4. Ammonium and mineral $\mathrm{N}$ contents $\left(\mathrm{N} \mathrm{kg} \mathrm{ha}^{-1}\right)$ of the $0-100 \mathrm{~cm}$ soil layer in June. Averages of 18 experiments and their standard error.

\begin{tabular}{|c|c|c|c|c|c|c|c|c|}
\hline \multirow[b]{2}{*}{ Treatment } & \multicolumn{4}{|c|}{ Ammonium } & \multicolumn{4}{|c|}{ Mineral $N$} \\
\hline & $(0)^{\star}$ & $(180)$ & * $(300)^{\star}$ & Mean & $(0)^{\star}$ & $(180)^{\star}$ & $(300)^{\star}$ & Mean \\
\hline Means & & & & & & & & \\
\hline Slurr & 10 & 41 & 58 & 37 & 93 & 300 & 402 & 265 \\
\hline $\mathrm{b}$ (slurry in autumn) & 22 & 44 & 76 & 47 & 231 & 403 & 531 & 388 \\
\hline$c$ (slurry in autumn $+D C D$ ) & 54 & 91 & 142 & 96 & 250 & 458 & 581 & 429 \\
\hline$d$ islurry in & 18 & 34 & 63 & 38 & 231 & 364 & 474 & 356 \\
\hline Standard errors of means & & $9.1^{t}$ & & 7.4 & & $14.4^{\ddagger}$ & & 11.5 \\
\hline
\end{tabular}

(0) (180) and (300): inorganic fertilizer $\mathrm{N}$ applied ( $\left.\mathrm{kg} \mathrm{ha}^{-1}\right)$.

- Except when comparing means within the same treatment $a, b, c$ or $d$; then the standard errors of means are 6.4 and $10.6 \mathrm{~kg} \mathrm{ha}^{-1}$ respectively. 


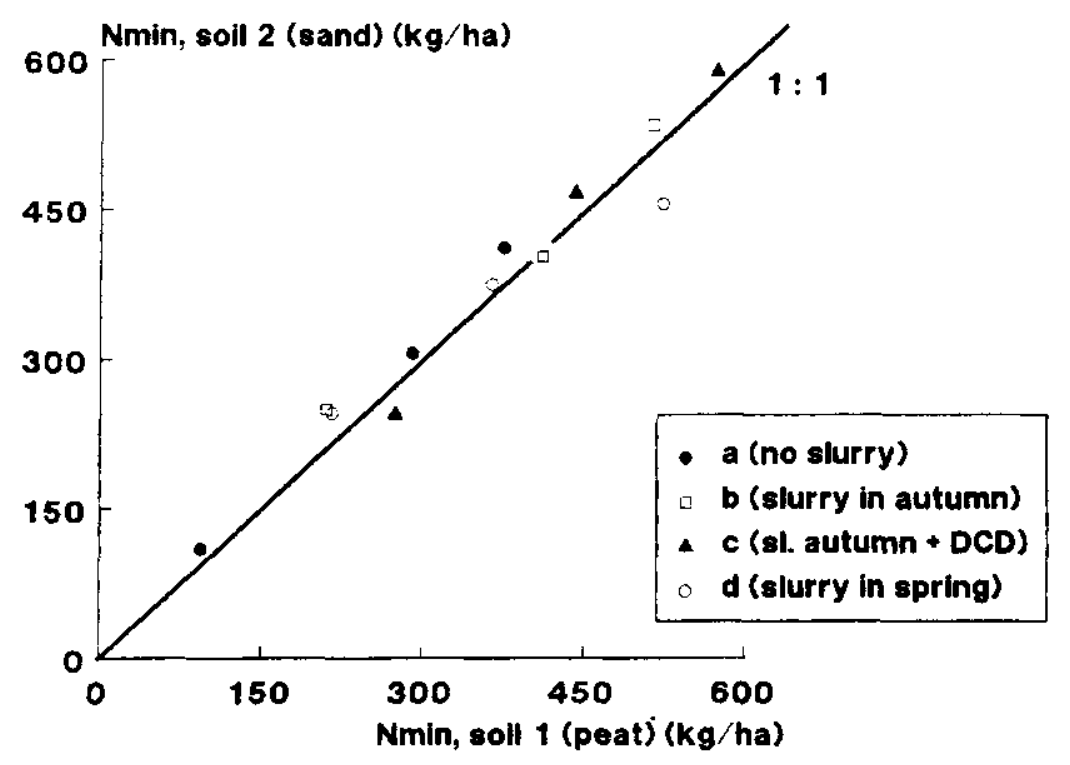

Fig. 1. Effect of soil type on soil mineral $\mathrm{N}$ (Nmin) content in fune $(0-100 \mathrm{~cm})$ following various treatments with slurry combined with inorganic $N$ fertilization. The line is the line of perfect agreement.

In June, soil mineral $\mathrm{N}$ was higher than in spring (Tables 3 and 4 ) due to mineralization (all treatments), inorganic fertilizer application (all treatments) and slurry application (treatment d). On average, DCD had increased soil mineral $\mathrm{N}$ by $41 \mathrm{~kg} \mathrm{ha}^{-1}$ (standard error $=16.3 \mathrm{~kg} \mathrm{ha}^{-1}$ ). This equals about the increase in ammonium content of the soil in June due to the application of DCD. The two soil types under consideration responded in much the same way with respect to the effect of the treatments on the mineral $\mathrm{N}$ content of the soil in June (Fig. 1).

As compared with treatment $a$, treatments $b, c$ and $d$ increased soil mineral $\mathrm{N}$ by 123,164 and $91 \mathrm{~kg} \mathrm{ha}^{-1}$, respectively (Table 4 , standard error $=$ $16.3 \mathrm{~kg} \mathrm{ha}^{-1}$ ). From the data in Table 2 it can be calculated that the $\mathrm{N}$ recovered from the autumn-applied slurry as soil mineral $\mathrm{N}$ in June amounted to $123 / 263=47 \%$ of the slurry $\mathrm{N}$ applied (standard error $=$ $16.3 / 263=6 \%$ ). The $\mathrm{N}$ recoveries from the autumn-applied slurry with DCD and from the spring-applied slurry amounted to $62 \%$ (standard error $=6 \%$ ) and $51 \%$ (standard error $=9 \%$ ) of the $\mathrm{N}$ applied with the slurry (and contained in DCD, $13 \mathrm{~kg} \mathrm{~N}^{-1}$, in treatment c) respectively. 
Table 5. Average fresh tuber yield of potatoes $\left(\mathrm{tha}^{-1}\right)$ grown for industrial starch production on the soil reclaimed from cut-over peat (Soil 1) and the sandy soil (Soil 2). Standard error of means on Soils 1 and 2 are 1.1 and 1.3 t ha ${ }^{-1}$ respectively (except when comparing means within the same treatment $a, b, c$ or $d$; then the standard errors of means on Soils 1 and 2 are 1.0 and 1.2 , respectively).

\begin{tabular}{lllllll}
\hline Treatment & \multicolumn{7}{l}{ Inorganic fertilizer N $\left(\mathrm{kg} \mathrm{ha}^{-1}\right)$} \\
\cline { 2 - 7 } & 0 & 60 & 120 & 180 & 240 & 300 \\
\hline Soil 1 (Peat) & & & & & & \\
a (no slurry) & 36.7 & 44.4 & 48.7 & 51.5 & 52.5 & 53.6 \\
b (slurry in autumn) & 49.5 & 52.5 & 55.4 & 53.7 & 54.8 & 52.8 \\
c (slurry in autumn + DCD) & 52.0 & 54.4 & 55.3 & 56.6 & 56.1 & 53.7 \\
d (slurry in spring) & 49.6 & 51.2 & 53.3 & 53.0 & 54.9 & 54.2 \\
Soil 2 (Sand) & & & & & & \\
a (no slurry) & 31.6 & 38.1 & 41.2 & 43.3 & 42.3 & 44.8 \\
b islurry in autumn) & 39.4 & 43.2 & 45.2 & 44.6 & 44.6 & 44.4 \\
c islurry in autumn + DCD) & 43.1 & 44.2 & 44.9 & 44.8 & 43.7 & 45.5 \\
d (slurry in spring) & 38.2 & 39.8 & 42.4 & 43.7 & 43.5 & 44.6 \\
\hline
\end{tabular}

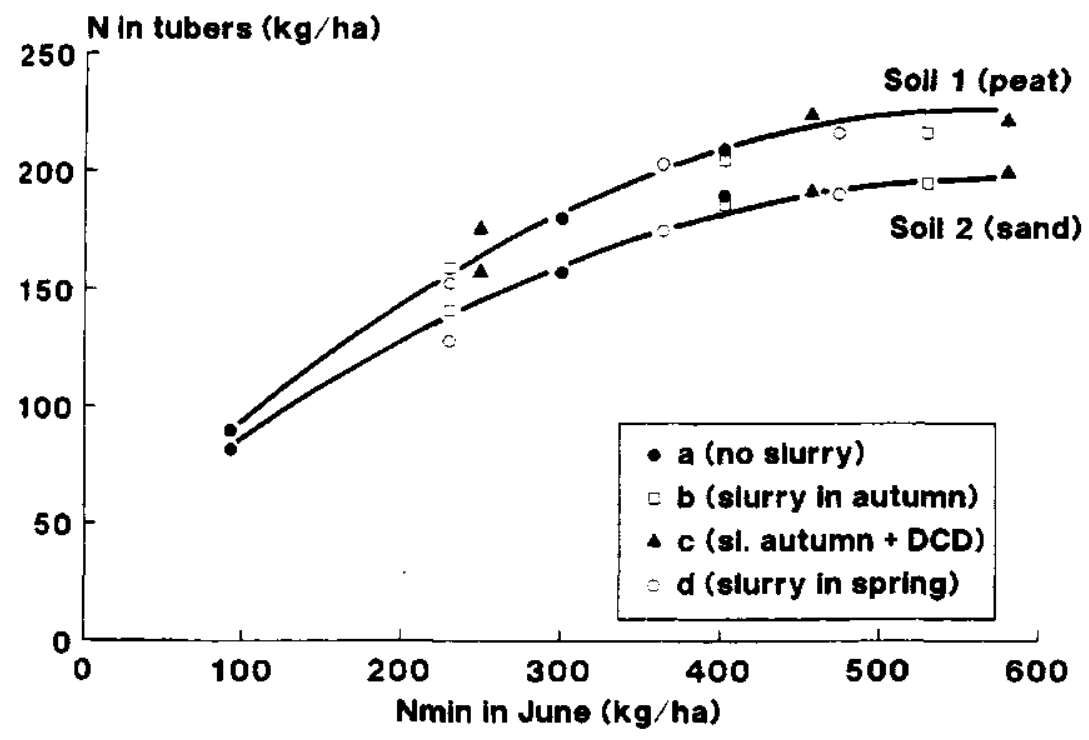

Fig. 2. Effect of soil mineral $N$ content $(\mathrm{Nmin})$ in lune $(0-100 \mathrm{~cm})$ following various treatments with slurry combined with inorganic $N$ fertilization on amount of $\mathrm{N}$ contained in the tubers at harvest. 


\section{$N$ response of potatoes}

The two soil types differed substantially in maximum yield level (Table 5). The different treatments led to differences in $\mathrm{N}$ supply. However, yields were apparently not only affected by differences in $\mathrm{N}$ supply, but also by other unknown factors connected with the different treatments on Soil 1 . When Tables 4 and 5 are combined it can be estimated that, at the optimum $N$ fertilization level, about $350 \mathrm{~kg} \mathrm{ha}^{-1}$ soil mineral $\mathrm{N}$ was present in June.

Figure 2 gives the amount of $\mathrm{N}$ in the potato tubers as affected by the supply of $N$ with slurry and inorganic fertilizer on both soil types. The values on the horizontal axis are the values of soil mineral $\mathrm{N}$ in June, taken from Table 4. Although the differences in amount of $\mathrm{N}$ in the tubers between the soil types are not as large as could be expected from the differences in maximum yield (Table 5), the higher yield level of Soil 1 resuited in a larger amount of $\mathrm{N}$ in the tubers. The results suggest that the amount of $\mathrm{N}$ in the tubers is closely related to the mineral $\mathrm{N}$ contents of the soil in June, irrespective of the form in which $\mathrm{N}$ was added in these experiments (Fig. 2).

\section{Residual soil mineral $\mathbf{N}$}

Contents of residual soil mineral $N$, i.e. soil mineral $N$ in the $0-100 \mathrm{~cm}$ layer at the harvest of the potatoes, are presented in Fig. 3. At the optimum level of $\mathrm{N}$ supply (soil mineral $\mathrm{N}$ in June was about $350 \mathrm{~kg} \mathrm{~N}^{-1}$ ) the amount of residual soil mineral $\mathrm{N}$ was about $110 \mathrm{~kg} \mathrm{~N} \mathrm{ha}^{-1}$. On average, the larger amount of $\mathrm{N}$ in the tubers on Soil 1 (Fig. 2) corresponds to a lower amount of residual soil mineral $\mathrm{N}$ in this soil type than that in Soil 2 (Fig. 3). At harvest the ammonium contents of the soil amounted to less than $10 \%$ of the mineral $\mathrm{N}$ contents of the soil.

The distribution of mineral $\mathrm{N}$ in the soil profile at harvest is given in Table 6. The layers $0-60 \mathrm{~cm}$ and $60-100 \mathrm{~cm}$ are both significantly affected by the application of organic and/or inorganic fertilizers $(P<5 \%)$. The differences between treatments $b$ and $c$ in Table 6 are small and not significant (at $P<$ $5 \%$ )

\section{DISCUSSION}

In slurry, $\mathrm{N}$ is present in an inorganic (mainly ammonium) and an organic form. Losses of inorganic $\mathrm{N}$ may seriously lower the efficiency of slurry $\mathrm{N}$ and adversely affect the environment. In the experiments reported here, the efficiency of slurry $\mathrm{N}$ was calculated from the amount of slurry $\mathrm{N}$ which 


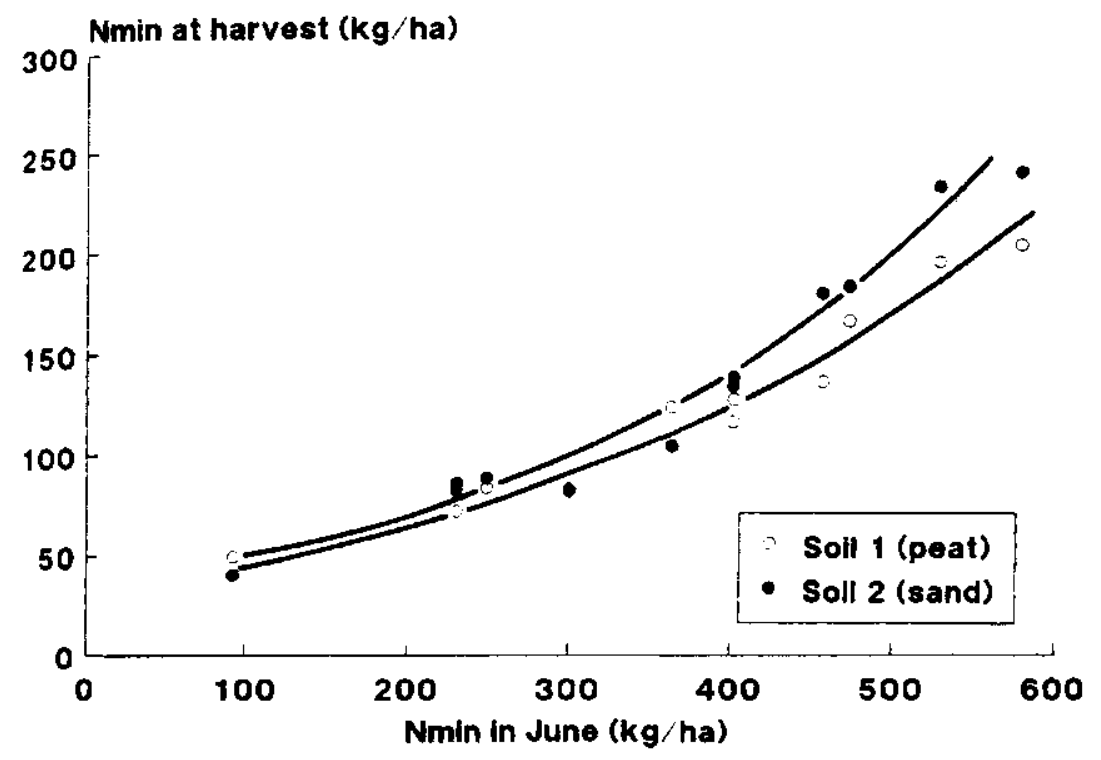

Fig. 3. Effect of soil mineral $N(\mathrm{Nmin})$ content in lune $(0-100 \mathrm{~cm})$ following iarious treatments with slurry combined with inorganic $\mathrm{N}$ fertilization on soil mineral $\mathrm{N}$ content $(0-100 \mathrm{~cm})$ at harvest.

Table 6. Soil mineral $N$ content of the $0-60$ and $60-100 \mathrm{~cm}$ layers at harvest. Averages of 18 experiments and their standard error.

\begin{tabular}{|c|c|c|c|c|c|c|c|c|}
\hline \multirow[b]{3}{*}{ Ireatment } & \multicolumn{8}{|c|}{ Soil mineral $N\left(\mathrm{~kg} \mathrm{ha}^{-1}\right)$} \\
\hline & \multicolumn{4}{|c|}{$0-60)(\mathrm{cm})$} & \multicolumn{4}{|c|}{$60-100(\mathrm{~cm})$} \\
\hline & $(0)^{\star}$ & $(180)^{*}$ & $(300)^{*}$ & Mean & $(0)^{\star}$ & $(180)^{\star}$ & $(300)^{\star}$ & Mean \\
\hline \multicolumn{9}{|l|}{ Means } \\
\hline it ino slurry) & 27 & 52 & 84 & 54 & 14 & 25 & 35 & 25 \\
\hline b) islurry in autumn) & 46 & 85 & 144 & 92 & 31 & 47 & 66 & 48 \\
\hline - islurry in autumn + DCD) & 53 & 103 & 160 & 105 & 28 & 45 & 56 & 43 \\
\hline d (slurry in spring) & 47 & 77 & 123 & 82 & 24 & 37 & 54 & 38 \\
\hline Standard errors of means & & $7.8^{\dagger}$ & & 4.8 & & $3.5^{*}$ & & 2.2 \\
\hline
\end{tabular}

. 10 ), (180) and (300): inorganic fertilizer $\mathrm{N}$ applied $\left(\mathrm{kg} \mathrm{ha}^{-1}\right)$.

$\cdot$ 'Except when comparing means within the same treatment $a, b, c$ or $d$; then the standard errors of means are 7.6 and $3.3 \mathrm{~kg} \mathrm{ha}^{-7}$ respectively. 
could be measured as soil mineral $\mathrm{N}$ in June. This method was preferred to the method of comparing the yield response to inorganic $\mathrm{N}$ fertilizers, because yield might be affected by factors other than the supply of $\mathrm{N}$ (see the section ' $\mathrm{N}$ response of potatoes'). Moreover, yield response to a wide range of levels of inorganic fertilizers was rather small in the experiments, so the scope for errors was great (Neeteson and Wadman, 1987). It was found that the $\mathrm{N}$ recovered in the soil as mineral $\mathrm{N}$ in June from autumn-applied poultry slurry amounted to $47 \%$ of the $N$ contained in the slurry applied. This is a rather high value, as Sluijsmans et al. (1978) have estimated that the efficiency index of autumn-applied slurry would be around $30 \%$. An explanation for the high recovery of autumn-applied slurry could be that nitrification was rather slow on these soils; in spring the ammonium content of the soil was substantially increased by the autumn-applied slurry.

Furthermore, in June, an increase in ammonium due to the application of the inorganic $\mathrm{N}$ fertilizer in April was observed.

The use of DCD increased the $\mathrm{N}$ recovery of autumn-applied slurry as soil mineral $\mathrm{N}$ in June: it was $62 \%$ of the $\mathrm{N}$ contained in the slurry applied ( $\mathrm{N}$ from DCD included). However, the amount of $\mathrm{N}$ saved by using DCD (about $41 \mathrm{~kg} \mathrm{ha}^{-1}$ ) would not cover the costs of DCD. This could have been caused in part by the high recovery of $\mathrm{N}$ from the autumn-applied slurry (without $D C D$ ). The recovery of $\mathrm{N}$ from the spring-applied slurry as soil mineral $\mathrm{N}$ in June was $51 \%$ of the $\mathrm{N}$ contained in the slurry. This is in good agreement with the efficiency index of $57 \%$, as can be estimated on the basis of the assumptions of Sluijsmans et al. (1978) for this type of slurry. On average, the efficiency of the spring-applied slurry is rather low compared with the autumn-applied slurry with DCD (the difference was not significant at $P<$ $5 \%$ ). An explanation might be that ammonia volatilization following slurry application was higher in spring. However, this was not verified in the field.

As a close relationship was found between soil mineral $\mathrm{N}$ in June and the amount of $\mathrm{N}$ found in the tubers (Fig. 3), the amount of soil mineral $\mathrm{N}$ in June appears to be a good measure of the differences in $\mathrm{N}$ supply to the crop due to the various slurry treatments. Apparently there was little difference between the slurry treatments in the amounts of $\mathrm{N}$ mineralized between June and the end of $\mathrm{N}$ uptake by the crop, which also contribute to the total $\mathrm{N}$ supply. In spring (March or April) a decrease in the soil mineral $\mathrm{N}$ content was observed due to $\mathrm{DCD}$ (not significant at $P<5 \%$, Table 3 ). This is neither in agreement with the observed tuber yields and the amount of $\mathrm{N}$ found in the tubers, nor with the soil mineral $\mathrm{N}$ data in June, which are all increased by the use of DCD (Tables 4 and 5, Fig. 2). Similar results were reported by Amberger (1986) for a loess soil, where DCD applied with slurry in the autumn affected the $\mathrm{N}$ response of silage maize grown the next year, but had no effect on the mineral $\mathrm{N}$ content of the soil in February. This was attributed to stronger sorption of ammonium. In the experiments described in this 
paper, stronger ammonium sorption does not explain the differences in the effects of DCD observed in spring and later in the season, because in these light soils strong sorption of ammonium is not a major process; also, high ammonium contents of the soil were observed in spring as a result of slurry application (with and without DCD) in the preceding autumn (Table 3 ).

The increase in $N$ recovery, due to addition of DCD to slurry applied in autumn, suggests that nitrate leaching was reduced. However, this increase may have been caused in part by a decrease in denitrification.

In a lysimeter experiment in which slurry was applied in autumn before sugar beets were grown, it was found that addition of DCD reduced nitrate leaching significantly $(P<5 \%)$ compared to slurry application without DCD (Gutser and Amberger, 1984). However, the amount of $\mathrm{N}$ leached increased from $71 \mathrm{~kg} \mathrm{ha}^{-1}$ when no slurry was applied to $91 \mathrm{~kg} \mathrm{ha}^{-1}$ when slurry was applied with DCD (the difference being significant, $P<5 \%$; Gutser and Amberger, 1984). So, to evaluate the usefulness of DCD combined with slurry in reducing nitrate leaching, the amount of nitrate leached from autumn-applied slurry with DCD should be known. This was not measured in these experiments.

When no fertilizer was applied the amount of residual soil mineral $\mathrm{N}$ was about $50 \mathrm{~kg} \mathrm{ha}^{-1}$. In experiments with sugar beet and winter wheat Neeteson et al. (1989) found that optimum rates of inorganic $\mathrm{N}$ fertilizer produced only slight increases in residual soil mineral $\mathrm{N}$ compared to the no-fertilizer treatment. In our potato experiments, application of even moderate amounts of inorganic and/or organic fertilizer $\mathrm{N}$ increased the amount of residual soil mineral $\mathrm{N}$. This may lead to increased leaching of nitrate in the next autumn and winter. The use of DCD increased the $N$ supply to the crop and, therefore, the residual soil mineral $\mathrm{N}$ content. The results suggest that the use of DCD in autumn prior to the growing season will not lead to extra residual soil mineral $\mathrm{N}$, provided that the amounts of additional inorganic $\mathrm{N}$ fertilizers are adjusted so as to take the effect of DCD into account.

\section{ACKNOWLEDGMENT}

The cooperation of the regional research centre 'Stichting Interprovinciaal Onderzoekcentrum voor de akkerbouw op zand- en veenkoloniale grond in Middenoost- en Noordoost-Nederland' is gratefully acknowledged.

\section{REFERENCES}

Allison, F. E., 1973. Soil Organic Matter and its Role in Crop Production, Amsterdam: Elsevier. pp. 637. 
Amberger, A., 1986. Potentials of nitrification inhibitors in modern N-fertilizer management. Zeitschrift für Pflanzenernahrung und Bodenkunde 149, 469-484.

de la Lande Cremer, L.C. N., 1986. Preliminary results with the nitrification inhibitor dicyandiamide (DCD) in the Netherlands. In Efficient Land Use of Sludge and Manure, Dam Kofoed, A., Williams, J. H. and L'Hermite, P. (eds) pp. 7-13. London: Elsevier.

Gutser, R. and Amberger, A., 1984. Nitratauswaschung nach Gülledüngung mit Didinzusatz. Landwirtsch. Forsch. Kongressband, 137-145.

Neeteson, J. J., Dilz, K. and Wijnen, G., 1989. N-fertilizer recommendations for arable crops. In Management Systems to Reduce Impact of Nitrates, Germon, J. C. (ed). Brussels: in press.

Neeteson, J. J. and Wadman, W. P., 1987. Assessment of economically optimum application rates of fertilizer $\mathrm{N}$ on the basis of response curves. Fertilizer Research $12,37-52$.

Ris, J., Smilde, K. W. and Wijnen, G., 1981. Nitrogen fertilizer recommendations for arable crops as based on soil analysis. Fertilizer Research 2, 21-32.

Slangen, J.H.G. and Kerkhof, P., 1984. Nitrification inhibitors in agriculture and horticulture. A literature review. Fertilizer Research 5, I-76.

Sluijsmans, C. M. J., van Dijk, T. A., Kolenbrander, G. J., de le Lande Cremer, L. C. N., Smilde, K.W. and Werkhoven, C. H. E., 1978. The spreading of animal excrement on utilized agricultural areas of the Community. 1. Scientific bases for limitation of quantities and criteria for rules thereon. Information on Agriculture no. 47 Brussels: Commission of the European Communities.

Vierveijzer, H. C., Lepelaar, A and Dijkstra, J., 1979. Analysemethoden voor Grond, Rioolslib, Gezvas en vloeistof. Haren: Institute for Soil Fertility.

Vilsmeier, K., 1980. Dicyandiamidabbau in Boden in Abhängigkeit von der Temperatur. Zeitschrift für Pflanzenernahrung und Bodenkunde 143, 113-118.

Wadman, W. P., Sluijsmans, C. M. J. and de la Lande Cremer, L. C. N., 1987. Value of animal manures: changes in perception. In Animal manure on grassland and fodder crops. Fertilizer or waste? van der Meer, H. G., Unwin, R. J., van Dijk, T. A. and Ennik, G. C. (eds), pp. 1-16. Dordrecht: Martinus Nijhoff. 
